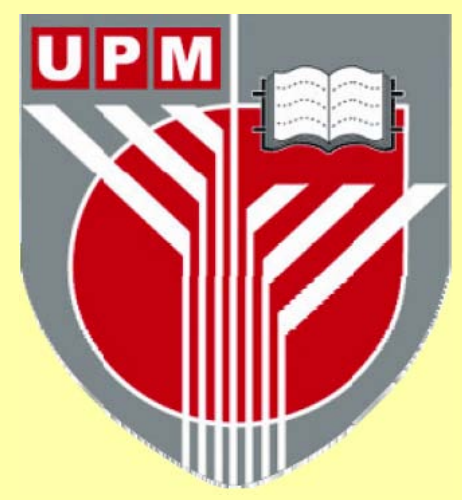

UNIVERSITI PUTRA MALAYSIA

DYNAMIC CHANNEL ALLOCATION FOR WIRELESS ATM

FEI WANG LI

FK 200053 
DYNAMIC CHANNEL ALLOCATION FOR WIRELESS ATM

By

FEI WANG LI

Thesis Submitted in Fulfilment of the Requirement for the

Degree of Master of Science in Faculty of Engineering Universiti Putra Malaysia

December 2000 
Abstract of the thesis presented to the Senate of Universiti Putra Malaysia in fulfilment of the requirement for the degree of Master of Science

\section{DYNAMIC CHANNEL ALLOCATION FOR WIRELESS ATM}

By

\section{FEI WANGLI}

December 2000

\section{Chairman: Associate Professor Borhanuddin Mohd. Ali, Ph.D.}

\section{Faculty: Engineering}

This thesis examines distributed Dynamic Channel Allocation (DCA) for the wireless environment through simulation. A wireless ATM network simulator was developed in $\mathrm{C}$ language. Performance is judged in terms of Normalized User Payload Throughput (NUPT), Percentage of Frequency Change (PFC), Ratio of Frequency Reuse (RFR), Frame Size $\left(F_{s}\right)$ and Frame Delay $\left(F_{d}\right)$ against traffic load. Some Distributed DCA channel selection strategies are examined, namely Two Frame Transmission (TFT) strategy, Access In Rotation (AIR) strategy and Intensive Access (IA) strategy. The performance of these strategies has been compared with Magic Wand Resource Reservation strategy first.

In the Two Frame Transmission (TFT) strategy, Access Point (AP) requests for a channel assignment every two frames, therefore the communication complexity is reduced. The Percentage of Frequency Change (PFC) is reduced by about $50 \%$, but the Normalized User Payload Throughput (NUPT) of TFT strategy is lower than Magic Wand Resource Reservation Strategy first. 
In the Access In Rotation (AIR) strategy, Mobile Terminals (MT) are divided into two groups, which access in rotation. In AIR strategy, the Normalized User Throughput (NUPT), and reduce Ratio of Frequency Reuse (RFR) are improved.

In the Intensive Access (IA) strategy, MTs access with a relative smaller interarrival. The simulation results show that the Normalized User Payload Throughput (NUPT) is improved when IA strategy is applied.

A criteria of performance evaluation has been developed to evaluate the performance of wireless ATM network, they are namely Stability factor of physical layer (SPHY), Stability factor of traffic load $\left(\mathrm{S}_{\mathrm{t}}\right)$, Ratio of Frequency Reuse (RFR). 
Abstrak tesis yang dikemukakan kepada Senat Universiti Putra Malaysia untuk memenuhi keperluan ijazah Master Sains

\section{PERUNTUKAN SALURAN DINAMIK UNTUK ATM TANPA WAYAR}

Oleh

\section{FEI WANGLI}

\section{Disember 2000}

Pengerusi: Profesor Madya Borhanuddin Mohd. Ali, Ph.D.

\section{Fakulti: Kejuruteraan}

Tesis ini mengkaji pengagihan peruntukan saluran dinamik untuk persekitaran ATM Tanpa Wayar melalui simulasi yang diaturcara dalam bahasa pengaturcaraan C. Prestasi dinilai berdasarkan Truput Pengguna Ternormal (NUPT), peratusan perubahan frekuensi (PFC), nisbah penggunaan semula frekuensi (RFR), saiz bingkai $\left(\mathrm{F}_{\mathrm{s}}\right)$ dan lengah masa tetingkap $\left(\mathrm{F}_{\mathrm{d}}\right)$ berbanding beban trafik. Tiga strategi pemilihan pengagihan saluran telah dikaji, iaitu strategi Penghantaran Dua Tetingkap (TFT), strategi Pencapaian Putaran (AIR) dan strategi Pencapaian Intensif (IA). Prestasi strategi-strategi ini telah dibandingkan dengan Strategi Pemesanan Sumber Magic Wand 1.

Pada strategi Transmisi Dua Tetingkap (TFT), Titik Pencapaian (Access Point) memohon satu peruntukan saluran untuk setiap dua tetingkap, maka kerumitan komunikasi dikurangkan. TFT juga boleh mengurangkan peratusan perubahan frekuensi sebanyak $50 \%$, tetapi Truput Pengguna Ternormal (NUPT) untuk strategi 
TFT adalah lebih rendah jika dibandingkan dengan Strategi Pemesanan Sumber Magic Wand 1.

Pada strategi Pencapaian Dalam Putaran (AIR), terminal boleh alih dibahagikan kepada dua kumpulan, yang membuat pencapaian secara bergilir. Strategi AIR boleh meningkatkan Truput Pengguna Ternormal (NUPT) dan mengurangkan nisbah penggunaan semula frekuensi.

Strategi Pencapaian Intensif (IA) merujuk kepada situasi di mana terminal boleh alih membuat pencapaian dengan ketumpatan yang tinggi. Hasil simulasi menunjukkan Truput Pengguna Ternormal (NUPT) dapat diperbaiki apabila strategi in dipraktikkan.

Satu kriteria pengujian prestasi telah dinumus untuk mengkaji prestasi rangkaian ATM tanpa wayar. Ia terdiri daripada faktor kestabilan, faktor kestabilan beban trafik dan nisbah penggunaan semula frekuensi. 


\section{ACKNOWLEDGEMENTS}

I would firstly like to thank IRPA for funding this wok. This thesis has been fully funded by Malaysian Govemment IRPA grant 04-01-04-0002. I also wish to express my thanks to some of the individuals who made this work possible. Foremost

of these is my supervisor, Dr. Borhanuddin Mohd. Ali, the chairman of my supervisory committee, gave me the opportunity to work on a very interesting and practical problem.

I am grateful to my two supervisors Mr. Ashraf Gasim Elsid Abdalla and Dr. V. Prakash for their time, support and patience and without which much of this work would not have been possible. My sincerest thanks go to Dr. Sabira for all her informative discussions and constructive suggestions during these graduate studies.

I am also glad to express my gratitude in particular to research team including without their support and advices, this work would not have been possible at all.

Finally, I would also like to thank my wife for giving me great support to proceed with the thesis. 
I certify that an Examination Committee met on $12^{\text {th }}$ December 2000 to conduct the final examination of Fei WangLi, on his Master of Science thesis entitled "Dynamic Channel Allocation for Wireless ATM" in accordance with Universiti Pertanian Malaysia (High Degree) Act 1980 and Universiti Pertanian Malaysia (High Degree) Regulations 1981. The Committee recommends that the candidate be awarded the relevant degree. Members of the Examination Committee are as follows:

SAMSUL BAHARI MOHD NOOR, Ph.D,

Lecturer,

Faculty of Engineering,

Universiti Putra Malaysia

(Chairman)

BORHANUDDIN MOHD.ALI, Ph.D,

Associate Professor,

Faculty of Engineering,

Universiti Putra Malaysia.

(Member)

ASHRAF GASIM ELSID ABDALLA

Lecturer,

Faculty of Engineering,

Universiti Putra Malaysia.

(Member)

VEERARAGHAVAN PRAKASH, Ph.D,

Lecturer,

Faculty of Engineering,

Universiti Putra Malaysia.

(Member)

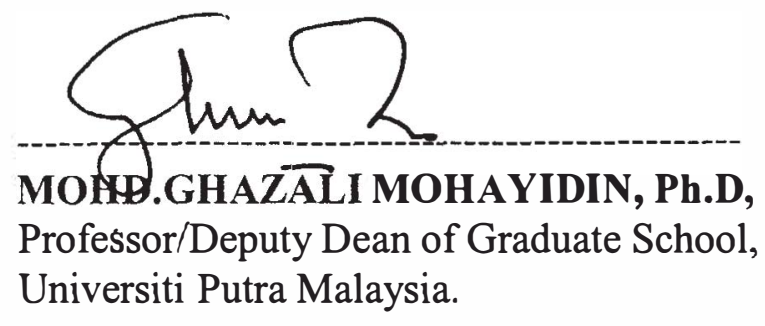

Date: 19 DEC 2000 
This thesis submitted to the Senate of Universiti Putra Malaysia has been accepted as fulfilment of the requirement for the degree of Master of Science.

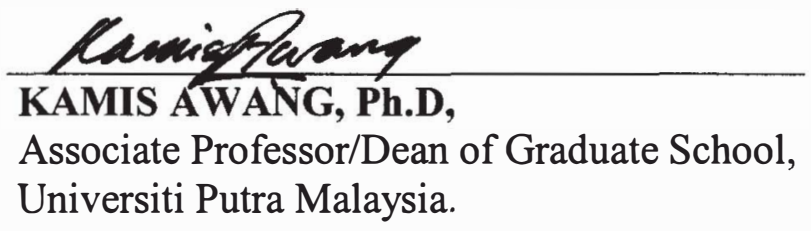

Date: 111 JAN 2001 
I hereby declare that the thesis is based on my original work except for quotations and citations which have been duly acknowledged. I also declare that it has not been previously or concurrently submitted for any other degree at UPM or other institutions.

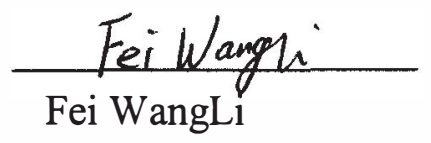

Date: $\operatorname{Dec} 192000$ 
ABSTRACT

Page

ABSTRAK

ACKNOLOWLEDGEMENTS

APPROVAL SHEETS

DECLARATION FORM

LIST OF TABLES

LIST OF FIGURES

LIST OF ABBREVIATIONS

LIST OF NOTATIONS

\section{CHAPTER}

\section{INTRODUCTION}

Wireless ATM Overview

Wireless ATM Architecture 4

Medium Access Control $\quad 6$

Data Link Control $\quad 8$

Physical Layer $\quad 8$

Propagation $\quad 9$

European Projects $\quad 10$

Overview of Channel Assignment Methods $\quad 11$

$\begin{array}{ll}\text { Objectives } & 14\end{array}$

Organization of This Thesis 15

II LITERATURE REVIEW

Introduction 17

$\begin{array}{ll}\text { Wireless Networks } & 17\end{array}$

$\begin{array}{ll}\text { Service Categories } & 18\end{array}$

$\begin{array}{ll}\text { Constant Bit Rate (CBR) Service } & 18\end{array}$

Real- Time Variable Bit Rate (rt-VBR) Service 20

Non-Real-Time Variable Bit Rate (nrt-VBR) Service $\quad 22$

Physical Layer of Magic WAND 23

Mobile Access Scheme Based on Contention And Reservation for ATM

(MASCARA) Time Frame

Time Slot Allocation in the Radio Link 27

MASCARA Scheduling Algorithm $\quad 28$

Dynamic Channel Allocation Strategies $\quad 30$

Distributed Channel Allocation Schemes $\quad 35$

Traffic Load Management $\quad 36$

Dynamic Cell Size Adjustment (DCESA) 36

Flow Control 38

Dynamic Bandwidth Allocation $\quad 39$

Conclusion 


\section{RESEARCH METHODOLOGY}

$\begin{array}{lr}\text { Introduction } & 42\end{array}$

Distributed Channel Allocation Scheme $\quad 42$

DCA Strategies in Simulation 43

Two Frame Transmission (TFT) Strategy 43

Access In Rotation (AIR) Strategy $\quad 45$

Intensive Access (IA) Strategy 46

Simulation Parameters $\quad 46$

Simulation Design $\quad 47$

VBR Source and Markov Chain $\quad 48$

$\begin{array}{lr}\text { Simulation Scenario } & 50\end{array}$

Simulation Modules $\quad 53$

Conclusion $\quad 54$

IV RESULTS AND DISCUSSIONS

Introduction $\quad 56$

Performance of Proposed Strategies

Two Frame Transmission (TFT) Strategy 56

Frame Delay $\quad 56$

Frame Size $\quad 58$

Percentage of Frequency Change (PFC) 58

Normalized User Payload Throughput (NUPT) 59

Ratio of Frequency Reuse (RFR) 59

Access In Rotation (AIR) strategy $\quad 60$

Normalized User Payload Throughput (NUPT) for S1 61

Percentage of Frequency Change (PFC) for S1 61

Ratio of Frequency Reuse (RFR) for S1 62

Normalized User Payload Throughput (NUPT) for TFT 63

Percentage of Frequency Change (PFC) for TFT 64

Ratio of Frequency Reuse (RFR) for TFT 65

Intensive Access (IA) strategy 66

Same Carrier (SC) algorithm vs. First Available Carrier (FAC) $\begin{array}{ll}\text { algorithm } & 68\end{array}$

Mutual Vectors in Wireless ATM Network $\quad 70$

Frame Size and Normalized User Payload Throughput 70

Cell Delay and Inter-arrival Time $\quad 73$

Access Inter-arrival and Frame Size 75

Frequency Reuse Ratio (RFR) and Transmission to Idle

Normalized User Payload Throughput (NUPT) and Frequency

$\begin{array}{ll}\text { Reuse Ratio (RFR) } & 80\end{array}$

Deviation of Traffic Load Factor, $\mathrm{L}_{\mathrm{t}} \quad 83$

$\begin{array}{lr}\text { Evaluation Parameters } & 84\end{array}$

Conclusion $\quad 86$

VI. CONCLUSIONS AND FUTURE WORKS
Introduction

Criteria of Performance Evaluation $\quad 88$

$\begin{array}{ll}\text { Future Works } & 90\end{array}$ 
Environment Learning Scheme

Proposed Reservation-Based Distributed DCA Schemes

REFERENCES

VITA 


\section{LIST OF TABLES}

Table

Page

1. Summary of European ACTS Projects 11

2. Typical Applications Using CBR Service Category 19

3. Range of values for rt-VBR parameters 20

4. Typical Applications Using rt-VBR Service Category 21

5. Typical applications using nrt-VBR service Category 22

6. Main PHY specifications of very high speed radio access 24

7. The scheduler class priorities 29

8. Comparison between DCA schemes 31

9. Simulation parameters $\quad 55$ 


\section{LIST OF FIGURES}

Figure

Page

1. Wireless ATM protocol stack 2

2. Wireless ATM reference architecture 4

3. Dynamic TDMA/TDD format for use in Wireless ATM 7

4. General Structure of the WAND MAC Time Frame 26

5. Packing of "cell train" within MPDU 27

6. Possible cell size variation of DCESA 37

7. The proposed Resource Reservation strategy 45

8. The Markov birth-death model used in simulation 50

9. The cell configuration used in the simulation 51

10. Simulator flow chart $\quad 52$

11. Comparison of S1 and TFT based on frame delay for load 2

12. Comparison of S1 and TFT based on frame size for load 2

13. Comparison of S1 and TFT based on PFC for load 2

14. Comparison of S1 and TFT based on NUPT for load 2

15. Comparison of S1 and TFT based on RFR for load $2 \quad 60$

16. Comparison of AIR and NonAIR strategy based NUPT for load 2 (S1) 61

17. Comparison of AIR and NonAIR strategy based on PFC for load 2 (S1) 62

18. Comparison of AIR and NonAIR strategy based on RFR for load 2 (S1) 63

19. Comparison of AIR and NonAIR strategy based on NUPT for load 2 (TFT)

20. Comparison of AIR strategies and NonAIR based on PFC for load 2 (TFT) 
21. Comparison of AIR and NonAIR strategy based on RFR for load 2 (TFT)

22. Comparison of IA-AIR and NonIA-AIR strategy based on NUPT (TFT) 67

23. Comparison of IA-AIR and NonIA-AIR strategy based on PFC (TFT) 67

24. Comparison of IA-AIR and NonIA-AIR strategy based on RFR (TFT) 68

25. NUPT comparison between SC and FAC algorithm 69

26. RFR comparison between SC and FAC Algorithm 69

27. Comparison of PFC between SC and FAC Algorithm 70

28. Frame size for load 1 and load 2 (TFT) 71

29. NUPT for load 1 and load 2 (TFT) 72

30. Frame size for NonAIR and AIR strategy (load 2) 72

$\begin{array}{ll}\text { 31. NUPT for S1 and AIR strategy (load 2) } & 73\end{array}$

$\begin{array}{ll}\text { 32. Uplink cell delay for S1 ( load 1) } & 74\end{array}$

33. Uplink cell delay for S1 (load 2) 74

34. NUPT for IA and NonIA strategies (load 2) 75

35. Frame size IA and NonIA strategies (load 2) 76

36. Comparison of RFR and UCH for S1 (load 1) 79

37. Comparison of RFR and UCH for S1 (load 2) 79

$\begin{array}{lr}\text { 38. Traffic load factor (load 2) } & 81\end{array}$

39. Traffic load factor (load 1) 82

40. RFR for IA and NonIA strategy (load 2) 82

41. NUPT for IA and NonIA strategy (load 2) 83

42. Gap between adjacent frames $\quad 84$

43. PFC for NonIA_NonAIR and IA-AIR strategy (load 2) 85

44. SPHY for NonIA-NonAIR and IA-AIR strategy (load 2) 85 


\section{LIST OF ABBREVIATION}

$\mathrm{ABR}$

AIR

AMPS

AP

ARQ

ATM

BER

BRAN

CBR

CIR

CLR

DCA

DCESA

DLL

DPSK

DSA

ETSI

FAC

FCA

FEC

FH

GSM

HIPERLAN
Available Bit Rate

Access In Rotation

Advanced Mobile Phone Service

Access Point

Automatic Retransmission reQuest

Asynchronous Transfer Mode

Bit Error Rate

Broadband Radio Access Networks

Constant Bit Rate

Carrier to Interference Ratio

Cell Loss Ratio

Dynamic Channel Allocation

Dynamic Cell Size Adjustment

Data Link Layer

Different Phase Shift Keying

Dynamic Slot Assignment

European Telecommunication Standards Institute

First Available Carrier

Fixed Channel Assignment

Forward Error Correction

Frame Header

Group Special Mobile

High Performance Radio Local Area Network 
HTA

IA

IntrA

ISDN

JVTOS

LAN

LFA

LIA

LOLIA

LTA

MAC

MASCARA

MBS

MIA

MPDU

MT

NUPT

OFDM

PCR

PCS

PDU

PFC

PHY

PSK
Highest interference below Threshold Algorithm

Intensive Access

Interarrival

Integrated Digital Service Network

Joint Viewing and Teleoperation Service

Local Area Network

Lowest Frequency below threshold Algorithm

Least Interference Algorithm

Locally Optimized Least Interference Algorithm

Least interference below Threshold Algorithm

Medium Access Control

Mobile Access Scheme based on Contention And Reservation for ATM

Mobile Broadband System

Marginal Interference Algorithm

MAC Protocol Data Unit

Mobile Terminal

Normalized User Payload Throughput

Orthogonal Frequency Division Multiplexing

Peak Cell Rate

Wireless personal communication service

Protocol Data Unit

Percentage of Frequency Change

Physical Layer

Phase Shift Keying 
QoS

Quality of Service

RFR

Ratio of Frequency Reuse

RSSI

Receive Signal Strength Indicator

$\mathrm{SC}$

Same Carrier

SCR

Sustain Cell Rate

TDD

Time Division Duplex

TDMA

Time Division Multiple Access

TFT

Two Frame Transmission

TS

Time Slot

UBR

Unspecified Bit Rate

VC

Virtual Channel

VBR

Variable Bit Rate

WAND

Wireless ATM Network Demonstrator

WATM

Wireless ATM

WLAN

Wireless Local Area Network 


\section{LIST OF NOTATIONS}

\begin{tabular}{|c|c|c|}
\hline ALPHA & - & ATM cell producing rate \\
\hline $\mathrm{L}$ & - & Traffic load \\
\hline $\mathrm{L}_{\mathrm{t}}$ & - & Traffic load factor \\
\hline $\mathrm{F}_{\mathrm{d}}$ & - & Frame delay \\
\hline$F_{\max }$ & - & Maximum frame size \\
\hline $\mathrm{F}_{\mathrm{s}}$ & - & Frame size \\
\hline $\mathrm{p}$ & - & OFF-ON transition \\
\hline $\mathrm{q}$ & - & ON-OFF transition \\
\hline $\mathrm{S}_{\mathrm{t}}$ & - & Stability factor of traffic load \\
\hline$\alpha$ & - & Probability factor \\
\hline$\lambda$ & - & Average arrival rate \\
\hline$\mu$ & - & Mean transmission rate \\
\hline$\mu$ & $\cdot$ & Average service rate \\
\hline$\sigma$ & - & Standard deviation \\
\hline$\sigma^{\prime}$ & - & Time increment \\
\hline
\end{tabular}




\section{CHAPTER I}

\section{INTRODUCTION}

\section{Wireless ATM Overview}

Wireless personal communication service (PCS) and broadband networking for the delivery of multimedia information represent two well established trends in telecommunications. While technologies for PCS and broadband communications have historically been developed somewhat independently, harmonization into a single architecture framework is motivated by an emerging need to extend multimedia services to a single portable terminals as well as by service integration and operational efficiency considerations. It is reasonable to consider extension of standard ATM services into next generation microcellular wireless and PCS scenarios (Yuan et al., 1997).

Future wireless networks however, will have to provide support for multimedia services (Ramanathan, 1999). With the growing acceptance of ATM as the standard for broadband networking, in which QoS is used to form a service contract between applications and the network (Chen et al, 1997), wireless ATM is emerging as a potential transport solution for broadband wireless networks. The interest for wireless multimedia services has grown rapidly (Berg, 1998), therefore provision of a flexible broadband wireless infrastructure that can support emerging multimedia services along with traditional data services is desirable (Kim and Krunz, 2000). In order to achieve this goal, wireless ATM must support the quality-of- 
service (QoS) requirements associated with various ATM services (Kim and Krunz, 1999). In such a system, the management of the available frequencies has a significant impact on system performance (Marias, 1998).

Mobile Teminal

\begin{tabular}{|c|l|}
\hline Aser process & \multicolumn{2}{|l|}{ ATM Control } \\
\hline ATM Adaption Layer & $\begin{array}{l}\text { Wire- } \\
\text { less } \\
\text { Con- } \\
\text { trol }\end{array}$ \\
\cline { 1 - 1 } ATM Network Layer & \\
\cline { 1 - 1 } $\begin{array}{l}\text { Data Link } \\
\text { Control }\end{array}$ & $\begin{array}{l}\text { Medium } \\
\text { Access Control }\end{array}$ \\
\hline High-speed radio \\
\hline
\end{tabular}

Wineless link header

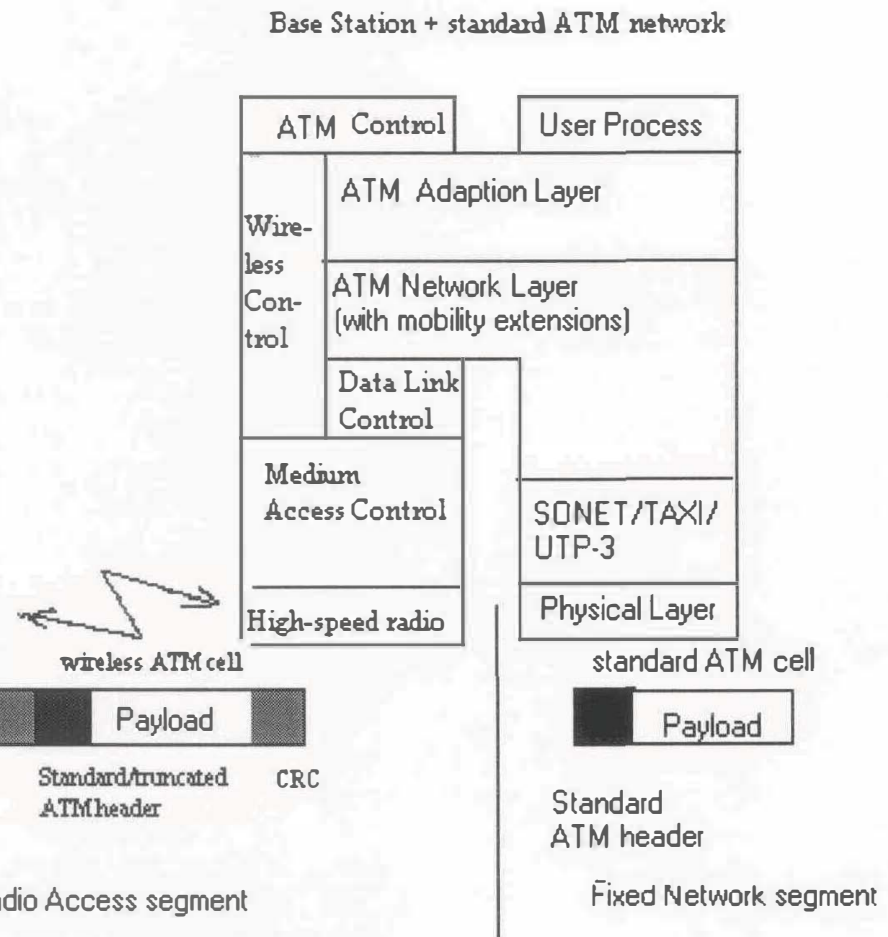

Figure 1. Wireless ATM protocol stack

The concept of wireless ATM is now being studied intensively and is still far from stable. The main advantage of Wireless ATM technology will be the seamless radio extension of ATM to mobile users. Today in most instances separate networks are used to carry voice, data, and video information, mostly because these traffic types have different characteristics. With ATM, separate networks will no longer be 
required. ATM is the only standards-based technology which has been designed from the beginning to accommodate the simultaneous transmission of data, voice, and video, improving efficiency as well as manageability (Fankhauser et al., 1996). In such a multi-service supported wireless environment, QoS guarantees are critical for real-time voice and video (Kim and Krunz, 1999). Data connections with relaxed time constraints can use Automatic Retransmission request (ARQ), while voice and video connections that require low delay, delay jitter, and minimal packet loss may need a combination of Forward Error Control (FEC) and ARQ with time-constrained retransmission (Kim and Krunz, 2000).

Some common features of most works on wireless ATM can however be identified (Mitts, 1996):

- Wireless ATM is viewed as a 'natural' extension of fixed ATM networks. It provides users wireless access to the multitude of services and applications expected to be deployed, over time, on fixed ATM networks. While this does not exclude dedicated wireless applications, they seem to play a lesser role.

- As an extension of fixed ATM networks, wireless ATM must embrace the key features of ATM networks such as the capability to provide bandwidth on demand and to support many different traffic classes (service categories) with different Quality of Service (QoS) objectives.

Wireless ATM systems are typically based on a cellular network layout with very small cells (micro or pico-cells). Due to the small cell size, handover between radio cells will be very frequent. The basic idea of wireless ATM is to use a standard 
ATM cell for network-level functions, while adding a wireless header/trailer on the radio link for wireless channel specific protocol sublayers. The proposed protocol stack is fully harmonized with that of standard ATM. Therefore, the normal ATM services, QoS and Q.2931 signaling can be used for mobile services.

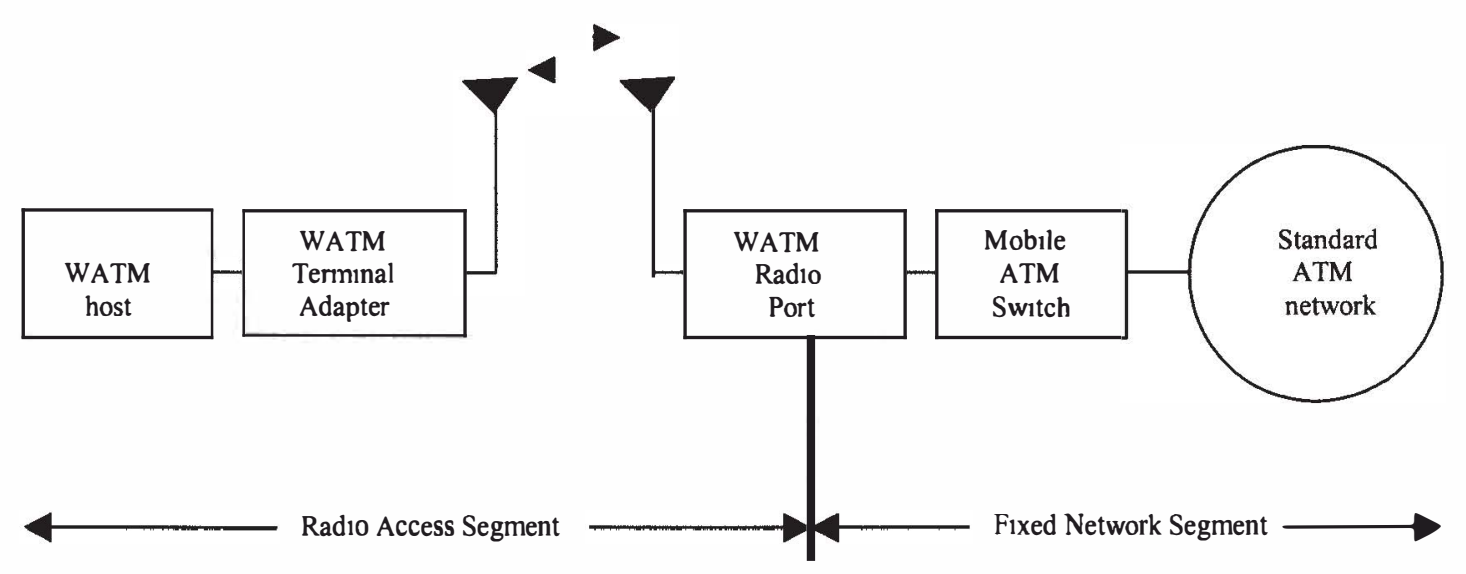

Figure 2. Wireless ATM reference architecture

\section{Wireless ATM Architecture}

Wireless ATM (WATM) system reference model mainly contains the following major components:

- WATM terminal: the end-user device.

- WATM terminal adapter: wireless ATM network interface at end user. 